\title{
Study of digoxin use in a public health unit
}

\author{
FELIPE C. SOUZA, EMILIANA B. MARQUES, \\ ROGÉRIO B.M. BARROS and CHRISTIANNE B.V. SCARAMELLO \\ Instituto Biomédico, Universidade Federal Fluminense (UFF), \\ Departamento de Fisiologia e Farmacologia (MFL), Laboratório de Farmacologia Experimental, \\ Rua Professor Hernani Pires de Melo, 101, São Domingos, 24210-130 Niterói, RJ, Brasil \\ Manuscript received on March 21, 2014; accepted for publication on October 26, 2014
}

\begin{abstract}
Digoxin is used for heart failure associated to systolic dysfunction and high ventricular rate. It has a narrow therapeutic range and intoxication may occur due to drug interactions or comorbidities. The aim of this work was to study digoxin use in a public health unit delineating the profile of patients susceptible to digitalis intoxication. Medical records belonging to patients admitted to the cardiomyopathy ward of the health unit (2009-2010) and in use of digoxin were analyzed. Among 647 patients admitted, 185 individuals using digoxin and possessed records available. The registration of plasma digoxin concentration was found in 80 records and it was out of the therapeutic range in 42 patients $(52.5 \%)$. This group of individuals was constituted mainly by males patients $(79 \%)$, functional class III of heart failure (65\%), exhibiting renal failure (33\%). The evaluated sample reflects the epidemiology of heart failure in Brazil and, although pharmacotherapy had been according to Brazilian Guidelines, apparently the monitoring was not performed as recommended. This work highlighs the necessity of plasma digoxin constant monitoring during pharmacotherapy and the development of protocols that enable a safer use, especially in male patients, functional class III and with renal dysfunction.
\end{abstract}

Key words: digoxin, intoxication, public health unit, therapeutic range.

\section{INTRODUCTION}

Digoxin is a drug that inhibits $\mathrm{Na}^{+} \mathrm{K}^{+}$ATPase active transport, raising cytosolic $\mathrm{Na}^{+}$concentration and consequently favoring $\mathrm{Ca}^{2+}$ uptake by the sarcoplasmic reticulum through the reversal of $\mathrm{Na}^{+} /$ $\mathrm{Ca}^{2+}$ exchange, leading to an increase of myocardial contractility (Ooi and Colucci 2003). It is indicated for patients with heart failure (HF) presenting systolic dysfunction, associated with high ventricular rate in atrial fibrillation, with current or prior symptoms (DIG, The Digitalis Investigation Group 1997). The

Correspondence to: Christianne Brêtas Vieira Scaramello

E-mail: chrisbretas@gmail.com
DIG study showed that hospitalization rate related to heart failure worsening is lower for patients taking digoxin than for patients on placebo, although there is no statistically difference about mortality between these groups.

Digoxin is commonly prescribed at a daily dose of 0.125 or $0.25 \mathrm{mg}$ per orally (Bocchi et al. 2009). Studies comparing serum digoxin levels with efficacy and safety show that concentrations between 0.5 and $0.9 \mathrm{ng} / \mathrm{mL}$ had greater benefit, including lower mortality and hospitalization, in men with left ventricular ejection fraction (LVEF) less than or equal to $45 \%$ (Rathore et al. 2003), in 
patients with HF (Ahmed et al. 2006, 2008) and in elderly patients with HF (Ahmed 2007).

Due to its narrow therapeutic range ( 0.8 to 2.0 $\mathrm{ng} / \mathrm{mL})$, also named therapeutic window, digoxin requires constant monitoring of plasma concentration (Cp) (Souza et al. 2013, Montera et al. 2009). Values of $\mathrm{Cp}$ above therapeutic range are associated with digitalis intoxication, a serious condition that involves cardiac arrhythmias, central changes, visual and gastrointestinal disturbances (Figueiredo and Machado 2010). Intoxication may occur due to drug interactions or health status that change digoxin pharmacokinetic parameters and can be avoided by the adjustment of digitalis therapeutic regimen (Ooi and Colucci 2003, Souza et al. 2013). In the elderly, a decrease about $50 \%$ of renal functional capacity is expected and this fact is associated to drugs accumulation in the body with consequent elevation of $\mathrm{Cp}$ for extended periods of time (Ewing 2002). Thus, this work aims to study digoxin use in a public health unit delineating the profile of patients with greatest risk of digitalis intoxication. This study was based on data, including digitalis $\mathrm{Cp}$, presented in the records of several patients using digoxin orally and admitted to the cardiomyopathy ward of a public health unit between 2009 and 2010 .

\section{MATERIALS AND METHODS}

This retrospective study was conducted through the inquiry of records belonging to patients admitted to the cardiomyopathy ward of the Instituto Nacional de Cardiologia (INC), a public health unit, between 2009 and 2010. The focus was inpatients using digoxin orally. Data, including this drug's Cp, were collected through individual forms and digoxin use pattern was analyzed by gender; age; functional class of HF (NYHA), if present; comorbidities and drug associations to digoxin. For these last two, just diseases/drugs with higher incidence were recorded.

This study was registered and approved by the Ethics Committee in Research of the INC, under no 0306/07-12-10.

\section{RESULTS}

During the period considered, 647 patients were admitted to the cardiomyopathy ward, and 194 made use of digoxin. However, only 185 records were available. Among the records analyzed, it was observed that 29 patients did not have HF. Among patients with HF (156), most were classified in the functional class III (NYHA) disease (52\%). Additionally, it was also observed that these subjects were mostly males (64\%), aged between 21 and 60 years-old (73\%), with comorbidities such as arterial hypertension (48\%), atrial fibrillation (37\%), renal failure (18\%) and who were using other drugs such furosemide (89\%), angiotensin-converting enzyme inhibitors (ACEI)/angiotensin receptor blockers (ARB) (78\%), carvedilol (60\%), enoxaparin (48\%), warfarin $(23 \%)$ and omeprazole (19\%) concomitantly to digoxin.

The registry of plasma digoxin levels was found only in $80(41 \%)$ of these available records being $\mathrm{Cp}$ out of the therapeutic range in 42 patients, i.e., $52.50 \%$ of these 80 subjects. Among patients with $\mathrm{Cp}$ out of the therapeutic range, 25 subjects (31.25\%) had records above the upper limit of 2.0 $\mathrm{ng} / \mathrm{mL}, 12$ patients $(15.00 \%)$ had records below the lower limit of $0.8 \mathrm{ng} / \mathrm{mL}$ and 5 patients $(6.25 \%)$ had records both above and below these limits (Table I).

TABLE I

Patients admitted to cardiomyopathy ward of the Instituto Nacional de Cardiologia between 2009 and 2010 who made use of digoxin and had accessible records presenting values of this drug plasma concentration $(\mathbf{n}=\mathbf{8 0})$

\begin{tabular}{c|c}
\hline $\begin{array}{c}\text { Digoxin plasma } \\
\text { concentration }\end{array}$ & $\begin{array}{c}\text { Number of } \\
\text { patients (\%) }\end{array}$ \\
\hline Within the therapeutic range & $38(47.50 \%)$ \\
\hline Out of the therapeutic range & $42(52.50 \%)$ \\
\hline Above the therapeutic range & $25(31.25 \%)$ \\
\hline Below the therapeutic range & $12(15.00 \%)$ \\
\hline $\begin{array}{c}\text { Above and below the } \\
\text { therapeutic range }\end{array}$ & $5(6.25 \%)$ \\
\hline
\end{tabular}

Signs of digitalis intoxication were occasionally described in the records of the patients with $\mathrm{Cp}$ above therapeutic window. It was admitted 
total adherence of these inpatients to treatment. Digoxin is administered in a standard daily dose of $0.125 \mathrm{mg}$ or $0.25 \mathrm{mg}$ to patients admitted to the cardiomyopathy ward of the Instituto Nacional de Cardiologia. These data are important because time and dosage of prescription impact the reach and maintenance of plasma concentration within the therapeutic window.

Table II details the profile of patients with digoxin $\mathrm{Cp}$ out of (42) and within (38) the therapeutic range. Most subjects were male in both groups, but the percentage of men among patients with $\mathrm{Cp}$ out of the therapeutic range (79\%) was higher than that of the group of patients with $\mathrm{Cp}$ within the therapeutic range $(68 \%)$. In both groups patients were mainly between 21-60 years-old, representing $76 \%$ and $77 \%$ of subjects with Cp out of and within the therapeutic window, being 41-60 years-old the predominant age range. The majority of those patients were also in functional class III, but the incidence of this class among patients with $\mathrm{Cp}$ out of the therapeutic range (65\%) was higher compared with patients with $\mathrm{Cp}$ within the therapeutic range (45\%).

TABLE II

Profile of the patients admitted to cardiomyopathy ward of the Instituto Nacional de Cardiologia between 2009 and 2010 who made use of digoxin and had accessible records presenting values of this drug plasma concentration $(n=80)$

\begin{tabular}{|c|c|c|c|}
\hline \multicolumn{2}{|c|}{ Digoxin plasma concentration } & \multirow{2}{*}{$\begin{array}{l}\text { Within the therapeutic } \\
\text { range }(n=38,100 \%)\end{array}$} & \multirow{2}{*}{$\begin{array}{l}\text { Out of the therapeutic } \\
\text { range }(n=42,100 \%)\end{array}$} \\
\hline & Stratification by & & \\
\hline Gender: & $\begin{array}{l}\text { Males } \\
\text { Females }\end{array}$ & $\begin{array}{l}26(68 \%) \\
12(32 \%)\end{array}$ & $\begin{array}{l}33(79 \%) \\
9(21 \%)\end{array}$ \\
\hline Age: & $\begin{array}{l}<20 \text { years-old } \\
21-40 \text { years-old } \\
41-60 \text { years-old } \\
>60 \text { years-old }\end{array}$ & $\begin{array}{c}1(3 \%) \\
12(32 \%) \\
17(45 \%) \\
8(20 \%)\end{array}$ & $\begin{array}{c}1(2 \%) \\
14(33 \%) \\
18(43 \%) \\
9(22 \%)\end{array}$ \\
\hline $\begin{array}{l}\text { Functional } \\
\text { class of heart } \\
\text { failure: }\end{array}$ & $\begin{array}{l}\text { Without heart failure } \\
\text { Functional class I } \\
\text { Functional class II } \\
\text { Functional class III } \\
\text { Functional class IV }\end{array}$ & $\begin{array}{c}1(3 \%) \\
2(5 \%) \\
6(16 \%) \\
17(45 \%) \\
12(31 \%)\end{array}$ & $\begin{array}{c}3(7 \%) \\
3(7 \%) \\
3(7 \%) \\
27(65 \%) \\
6(14 \%)\end{array}$ \\
\hline Comorbidity: & $\begin{array}{l}\text { Systemic Arterial Hypertension } \\
\text { Atrial Fibrillation } \\
\text { Renal Failure } \\
\text { Dyslipidemia } \\
\text { Diabetes Mellitus }\end{array}$ & $\begin{array}{l}20(53 \%) \\
17(45 \%) \\
8(21 \%) \\
3(8 \%) \\
10(26 \%)\end{array}$ & $\begin{array}{l}19(45 \%) \\
19(45 \%) \\
14(33 \%) \\
6(14 \%) \\
5(12 \%)\end{array}$ \\
\hline $\begin{array}{l}\text { Drug } \\
\text { association } \\
\text { with digoxin: }\end{array}$ & $\begin{array}{l}\text { Furosemide } \\
\text { ACEI/ARB } \\
\text { Enoxaparin } \\
\text { Carvedilol } \\
\text { Omeprazole } \\
\text { Warfarin }\end{array}$ & $\begin{array}{l}36(95 \%) \\
33(87 \%) \\
25(66 \%) \\
21(65 \%) \\
17(45 \%) \\
10(26 \%)\end{array}$ & $\begin{array}{l}39(93 \%) \\
32(76 \%) \\
27(64 \%) \\
23(55 \%) \\
20(48 \%) \\
13(31 \%)\end{array}$ \\
\hline
\end{tabular}

With regards to comorbidities, table II also shows that the incidence of hypertension and atrial fibrillation was similar between patients with $\mathrm{Cp}$ out of and within the therapeutic range. Differences seem to be present between these groups with regard to renal failure, dyslipidemia and diabetes mellitus incidence. However, differences regarding drug combinations with digoxin were not noteworthy.

\section{DISCUSSION}

Acute heart failure can be defined as a rapid onset or change in clinical signs and symptoms of HF, 
resulting in urgent need for therapy. Acute HF can also be due to new or worsening of pre-existing HF (chronic decompensated HF) (Ewing 2002). According to Bocchi et al. (2009), data from Unified Health System (Sistema Único de Saúde, SUS) show that the highest number of hospitalizations and deaths encompasses males of 20-59 years-old in Brazil. In the last census (2010) it was observed that the elderly population is increasing in this country and consequently, so is the frequency of at-risk patients or patients with HF. The prevalence of HF with reduced LVEF in men was ratified (Bocchi et al. 2012).

The cardiomyopathy ward of INC is a specialized inpatient unit of $\mathrm{HF}$ and cardiac transplantation. This justifies the fact that most patients taking digoxin in the present study are in class III regarding the disease severity. It was also observed that these subjects were predominantly male, aged between 21 and 60 years, reflecting the data reported by Unified Health System.

In general systolic dysfunction is found in $55 \%$ of patients with decompensated heart failure, with hypertension being the second most common etiology (20.8\%) (Bocchi et al. 2012). Atrial fibrillation affects about $20 \%-30 \%$ of patients with acute HF and can conceptually result in reduced contractility and cardiac output, with deterioration of diastolic dysfunction and exacerbation of acute HF (Montera et al. 2009). The prevalence of renal failure in outpatients with $\mathrm{HF}$ can reach $29.6 \%$. The association of cardiac and renal disease persists as a marker of bad prognosis in patients with chronic HF (Bocchi et al. 2012). So the present work suggests that the population studied in this work reflects Brazilian reality since comorbidities such as hypertension (45\%), atrial fibrillation (45\%) and renal insufficiency (33\%) were frequently observed in patients with $\mathrm{Cp}$ of digoxin out of the therapeutic range in which the subjects were mostly males with ages ranging from 21 to 60 years-old.

Literature demonstrates a progressive increase in serum digoxin levels related to a decrease of digitalis renal clearance due to age (Souza et al. 2013, Yukawa et al. 2011). The reduction of digoxin clearance to about $50 \%$ of its normal value $(0.80 \mathrm{~mL} /$ $\mathrm{min} / \mathrm{kg}$ ) results in an increased half-life (Yukawa et al. 2011), which can favor values of $\mathrm{Cp}$ out of the therapeutic range, as observed in this study with patients with renal failure using digitalis (33\%).

Digoxin is not prescribed as an inotropic in acute HF. The digitalis is indicated for symptomatic chronic HF patients with LVEF less than 45\% and optimized betablocker and ACE inhibitor therapy presenting sinus rhythm (aiming symptoms improvement - Class of recommendation I, level of evidence A) or in cases of atrial fibrillation occurrence (focusing on heart rate control - Class of recommendation I, level of evidence C). It is contraindicated for individuals with asymptomatic sinus rhythm or with an LVEF equal to or greater than $45 \%$ (class of recommendation III, level of evidence C) (Bocchi et al. 2012). In the present study, we observed that this drug was correctly prescribed to inpatients of the cardiomyopathy ward during the evaluated period.

DIG study demonstrated an association between $\mathrm{Cp}$ of digoxin and its clinical benefit. During three years of observation, there was a reduction in mortality and even a decrease of hospitalizations due to $\mathrm{HF}$ related to patients with $\mathrm{Cp}$ between 0.5-0.9 ng/mL (The Digitalis Investigation Group 1997). As Cp interferes in the benefit related to digitalis, its measurement should be performed to ensure the maintenance of the levels within 0.5$0.9 \mathrm{ng} / \mathrm{mL}$ (Montera et al. 2009). Nevertheless in this study it was observed that this measurement was not performed in most of the patients admitted to the cardiomyopathy ward of the INC between 2009 and 2010 whose records were available and $\mathrm{Cp}$ values had been registered. The $\mathrm{Cp}$ evaluation of digoxin must be done between 12-24 hours after the last dose (Montera et al. 2009).

Digoxin has vagomimetic and simpaticoinhibitory properties which contribute to heart rate control 
effectiveness when associated to betablockers, especially in patients with atrial fibrillation. Although this drug has not been tested in randomized clinical trials, digitalis is recommended associated to beta blockers, or even before its introduction, aiming towards the control of heart rate in patients with decompensated HF presenting systolic dysfunction, atrial fibrillation and ventricular response lower than 80 bpm (Montera et al. 2009).

Pharmacokinetic interaction between carvedilol and digoxin has been previously reported. This betablocker increases digoxin serum levels when administered concomitantly to digitalis via oral route. This is possible because these two drugs are glycoprotein P substrates (Baris et al. 2006). Men seem to present higher activity of glycoprotein $\mathrm{P}$ compared to women, so literature suggests that this drug interaction would be clinically significant in males, leading to this digitalis bioavailability increase and the obtainment of digoxin $\mathrm{Cp}$ values out of the therapeutic range (Baris et al. 2006) as observed in this study.

Betablockers prolong life and reduce the risk of disease progression in patients with chronic HF. They present class of recommendation I for $\mathrm{HF}$ treatment, including asymptomatic systolic dysfunction, and level of evidence A or $\mathrm{B}$ depending on the presence or the absence of symptoms, respectively. When associated to ACEI/ $\mathrm{ARB}$, these drugs demonstrate clinical benefit in overall mortality due to HF and sudden death, lead to symptoms improvement and reduction of HF readmission (Bocchi et al. 2012).

In the present work it was also noted that $78 \%$ of patients taking digoxin did so concomitantly to $\mathrm{ACEI} / \mathrm{ARB}$ use, and this association was more frequent among subjects with $\mathrm{Cp}$ within therapeutic range $(87 \%)$ than among patients with values of $\mathrm{Cp}$ out of these limits (76\%). According to the study of Kirimli et al. (2001), no evidence of toxicity was observed in patients using digoxin associated to captopril, an ACE inhibitor. De Smet et al. (1995) showed that multiple oral doses of the ARB losartan did not alter digoxin pharmacokinetics, regardless whether the drug was being administered orally or intravenous ly. ACEI and ARB are recommended for chronic use in cases of asymptomatic and symptomatic left ventricular dysfunction (class of recommendation I, level of evidence A) (Bocchi et al. 2012).

The use of these drugs by patients with acute HF is related to pre and afterload decrease. Several strategies have been discussed regarding the use of intravenous vasodilator to attain this purpose. The use of ACEI/ARB during the management of a decompensation episode must be judiciously evaluated and it is important to identify patients with decompensated HF who use these medications chronically from those who do not. Treatment with these drugs should be kept to maintain a more stable clinical course in patients on chronic use in the absence of contraindications (history of angioedema, bilateral renal artery stenosis, severe aortic stenosis, potassium serum levels above 5.0 $\mathrm{mEq} / \mathrm{L}$, creatinine serum levels greater than 2.5 $\mathrm{mg} / \mathrm{dL}$, hypotension with evidence peripheral hypoperfusion, recent worsening of renal function) (Montera et al. 2009).

Intravenous diuretics are indicated to improve symptoms of hypervolemia and congestion in decompensated HF, however they are deleterious to the renal function in the long run (Montera et al. 2009). The class of recommendation of loop diuretics is I in patients with symptomatic chronic $\mathrm{HF}$, presenting signs and symptoms of congestion, being $C$ the level of evidence (Bocchi et al. 2012). As seen in this and other studies, the combination digoxin/furosemide is very common (Moura et al. 2009). A pharmacodynamic interaction is observed during this drug association because loop diuretics are kaliuretics (Montera et al. 2009) and the bind of the digitalis to its pharmacological receptor is favored when potassium extracellular levels are decreased (Ooi and Colucci 2003). However, it 
is important to note that this pharmacodynamic interaction does not change $\mathrm{Cp}$ values of digoxin (Brown et al. 1976) although may precipitate or contribute to arrhythmias development, especially in patients with preexisting cardiac anomalies. These effects can be prevented by dietary sodium restriction or addition of potassium sparing diuretics (Moura et al. 2009).

Hospitalization due to acute HF is a recognized risk factor for the occurrence of venous thromboembolism, so thrombosis prophylaxis should be performed using low doses of unfractionated heparin or low molecular weight heparin during confinement period in bed (Class of recommendation I, level of evidence C). Atrial fibrillation increases the risk of thromboembolic events in patients with HF in a significant manner (Montera et al. 2009). The class of recommendation for coumarins, such as warfarin, is I, level of evidence A, for patients presenting LVEF lower than 35\% in paroxysmal, persistent or permanent atrial fibrillation accompanied by at least one additional risk factor. Bleeding risk with oral anticoagulants leads to the need of their replacement by acetylsalicylic acid, an antiplatelet drug. Low molecular weight heparins, such as enoxaparin, were used in combination with digitalis by the patients admitted to the cardiomyopathy ward of the INC between 2009 and 2010 whose records were available and $\mathrm{Cp}$ values registered, although they are for emergency use. The description of pharmacokinetic interaction between enoxaparin and digoxin was not found in the literature. However, enoxaparin should be used with caution in patients with creatinine clearance lower than 30 $\mathrm{mL} / \mathrm{min}$ (Montera et al. 2009). It is noteworthy that in this study $33 \%$ of patients with $\mathrm{Cp}$ values of digoxin out of the therapeutic range presented renal dysfunction and enoxaparin was administered in $64 \%$ of these individuals.

This work also showed drug association between digoxin and omeprazole. About half of the patients who had $\mathrm{Cp}$ values of digoxin registered took this drug together with omeprazole. No relevant difference was observed between patients with $\mathrm{Cp}$ values of digoxin out of the therapeutic range and individuals with $\mathrm{Cp}$ within these limits. Proton pump inhibitors, such as omeprazole, are drugs widely prescribed and they are not associated to important adverse effects or drug interactions, although they are cytochrome P450 enzyme substrate (Oosterhuis 1991). In the study conducted by Oosterhuis et al. (1991) it is shown that the use of omeprazole concomitantly to digoxin caused a small increase in oral absorption of this digitalis but this increase was considered clinically irrelevant. However, Kiley et al. (2007) reported symptoms of digitalis toxicity in 65 years-old woman on longterm digoxin therapy, with history of $\mathrm{Cp}$ values within therapeutic range and absence of renal or hepatic insufficiency, three months after the beginning of this drug association. In this case, no other change in pharmacotherapy had been performed beyond the prescription of omeprazole.

This study demonstrates that a great number of patients admitted to the cardiomyopathy ward of INC use digoxin during hospitalization. The evaluated sample reflects the epidemiology of $\mathrm{HF}$ in Brazil and the treatment protocol applied by this public health unit is in accordance to Brazilian Guidelines on Acute and Chronic Heart Failure (Montera et al. 2009, Bocchi et al. 2012). However, registration of $\mathrm{Cp}$ values was not performed for all patients making use of digoxin, as recommended. This approach needs to be reviewed since $\mathrm{Cp}$ levels of digoxin were found out of the therapeutic range in about half of the individuals whose $\mathrm{Cp}$ was monitored.

Data from this work highlight the importance for serum digoxin close monitoring during pharmacotherapy to guide its rational use and avoid digitalis intoxication. This study indicates the profile of patients who are more susceptible to develop digitalis toxicity: males, HF functional 
class III (NYHA) who are exhibiting renal failure. There are some studies about pharmacokinetics of digoxin using healthy volunteers but the shown data substantiate the need of digoxin pharmacokinetic studies involving patients with $\mathrm{HF}$ in order to enable a safer prescription of digoxin.

\section{RESUMO}

A digoxina é usada para insuficiência cardíaca associada à disfunção sistólica e alta frequência ventricular. Possui janela terapêutica estreita, e a intoxicação pode ocorrer por interações medicamentosas ou comorbidades. O objetivo deste trabalho foi estudar o uso de digoxina em uma unidade pública de saúde, determinando o perfil de pacientes susceptíveis à intoxicação digitálica. Foram analisados dados de prontuários de pacientes internados na enfermaria de cardiomiopatia (2009-2010) em uso de digoxina. Dentre 647 indivíduos admitidos, 185 fizeram uso de digoxina e tiveram prontuário disponibilizado. A concentração plasmática de digoxina encontrava-se registrada em 80 prontuários, e estando fora da janela terapêutica em 42 pacientes $(52,50 \%)$. Este grupo de indivíduos foi constituído principalmente por pacientes do sexo masculino (79\%), em classe funcional III de insuficiência cardíaca (65\%), apresentando insuficiência renal (33\%). A amostra analisada refletiu a epidemiologia da insuficiência cardíaca no Brasil e, embora a farmacoterapia tenha se dado de acordo com as Diretrizes Brasileiras, o monitoramento aparentemente não foi realizado como sugerido. Este trabalho ratifica a necessidade de monitoramento constante da concentração plasmática do digitálico durante a farmacoterapia e o desenvolvimento de protocolos que permitam utilização mais segura principalmente em pacientes do sexo masculino, em classe funcional III e com disfunção renal.

Palavras-chave: digoxina, intoxicação, unidade pública de saúde, faixa terapêutica.

\section{REFERENCES}

AHMED A. 2007. Digoxin and Reduction in Mortality and Hospitalization in Geriatric Heart Failure: Importance of Low Doses and Low Serum Concentrations. J Gerontol A Biol Sci Med Sci 62(3): 323-329.
Ahmed A, Pitt B, Rahimtoola SH, WaAgstein F, White M, LOVE TE AND BRAUNWALD E. 2008. Effects of digoxin at low serum concentrations on mortality and hospitalization in heart failure: A propensity-matched study of the DIG trial. Int J Cardiol 123: 138-146.

AhMed A, Rich MW, Love TE, Lloyd-Jones DM, ABAN LB, Colucci WS, AdAms KF AND GHEORGHiAdE M. 2006. Digoxin and reduction in mortality and hospitalization in heart failure: a comprehensive post hoc analysis of the dig trial. Eur Heart J 27: 178-186.

BARIS N, KALKAN S, GÜNERI S, BOZDEMIR V AND GUVEN H. 2006. Influence of carvedilol on serum digoxin levels in heart failure: is there any gender difference? Eur J Clin Pharmacol 62: 535-538.

BOCCHI EA ET AL. 2009. III Diretriz Brasileira de Insuficiência Cardíaca Crônica. Arq Bras Cardiol 93: 1-71.

BocChi EA ET AL. 2012. Sociedade Brasileira de Cardiologia. Atualização da Diretriz Brasileira de Insuficiência Cardíaca Crônica - 2012. Arq Bras Cardiol 98(1 Supl. 1): 1-33.

BROWN DD, DORMOIS JC, ABRAHAM GN, LEWIS K AND DIXON K. 1976. Effect of furosemide on the renal excretion of digoxin. Clin Pharmacol Ther 20(4): 395-400.

De Smet M, Schoors DF, De Meyer G, Verbesselt R, Goldberg MR, FitzPATRICK V AND SOMERS G. 1995. Effect of multiple doses of losartan on the pharmacokinetics of single doses of digoxin in healthy volunteers. Br J Clin Pharmacol 40: 571-575.

DIG - The Digitalis InVESTigation Group. 1997. The Effect of Digoxin on Mortality and Morbidity in Patients with Heart Failure. N Engl J Med 336: 525-533.

EWING AB. 2002. Altered drug response in the elderly. In: Armour D and Cairns C (Eds), Medicines in the elderly. London: Pharmaceutical Press, p. 15-27.

FigueIREdo EL AND Machado FP. 2010. Digoxin's roles in heart failure patients: An overview. Insuf Card 5(2): 59-64.

KILEy CA, CRAgIn DJ AND Roth BJ. 2007. Omeprazoleassociated digoxin toxicity. South Med J 100(4): 400-402.

Kirimli O, Kalkan S, GUNERI S, TUNCOK Y, AKDENIZ B, OZDAMAR M AND GUVEN H. 2001. The effects of captopril on serum digoxin levels in patients with severe congestive heart failure. Int J Clin Pharmacol Ther 39(7): 311-314.

MONTERA MW ET AL. 2009. Sociedade Brasileira de Cardiologia. II Diretriz Brasileira de Insuficiência Cardíaca Aguda. Arq Bras Cardiol 93(3 Supl. 3): 1-65.

Moura C, ACurcio F AND Belo N. 2009. Drug-Drug Interactions Associated with Length of Stay and Cost of Hospitalization. J Pharm Pharmaceut Sci 12(3): 266-272.

OoI H AND COLUCCI WS. 2003. Tratamento farmacológico da insuficiência cardíaca. In: Coelho $\mathrm{T}$ and Carvalho SB (Eds), Goodman \& Gilman's As bases farmacológicas da terapêutica. $10^{\mathrm{a}}$ ed., Rio de Janeiro. McGraw-Hill. Tradução: Carla de Mello Vorsatz, p. 679-702.

OOSTERHUIS B, JONKMAN JHG, ANDERSSON T, ZUIDERWIJK PBM AND JEDEMA JN. 1991. Minor effect of multiple dose omeprazole on the pharmacokinetics of digoxin after a single oral dose. Br J Clin Pharmac 32: 569-572. 
RATHORE SS, CURTIS JP, WANG Y, BRISTOW MR AND KRUMHOLZ HM. 2003. Association of serum digoxin concentration and outcomes in patients with heart failure. JAMA 289: 871-878.

Souza FC, Marques EB AND Scaramello CBV. 2013. Variações interindividuais na farmacocinética clínica de cardiotônicos. Rev Bras Cardiol 26(3): 213-220.
Yukawa M, YuKawa E, SuEMatsu F, TAKIGUCHI T, IKeDA H, AKI H AND Mimemoto M. 2011. Determination of Digoxin Clearance in Japanese elderly Patients for Optimization of Drug Therapy. Drugs Aging 28(10): 831-841. 